\title{
Scientific note: colony losses survey in Turkey and causes of bee deaths*
}

\author{
Tugrul GIRAY ${ }^{1}$, Meral KencE ${ }^{2}$, Devrim OsKAY ${ }^{3,4}$, Mehmet Ali DöKE ${ }^{2}$, Aykut KencE ${ }^{2}$ \\ ${ }^{1}$ University of Puerto Rico, POB 23360, San Juan, PR, 00931 USA \\ ${ }^{2}$ Middle East Technical University, Department of Biology, 06531, Ankara, Turkey \\ ${ }^{3}$ Washington State University, Pulmann, WA, USA \\ ${ }^{4}$ Current adress: Namik Kemad University, Department of Agricultural Biotechnology, 59030 Tekirdag, Turkey
}

Received 1 July 2009 - Revised 3 September 2009 - Accepted 9 September 2009

Anatolia / bee deaths / climate / bee races / CCD

There have been unexpected and alarming colony losses in different regions of the world in the past few years (reviewed in Oldroyd, 2007; EFSA, 2008; see also vanEngelsdorp et al., 2008). Concurrent with those in the US, high colony losses also were reported in Turkey (Giray et al., 2007). Health of honey bees in Turkey is of general importance, both because of native honey bee biodiversity (see Bodur et al., 2007; reviewed in Kence, 2006) and a high number of domestic colonies ( $>5$ million; FAOSTAT, 2008), which is second only to China. We investigated the extent and causes of losses in Turkey using a questionnaire study, which was conducted in 2007 and covered the three previous years.

This report includes analyses of 288 questionnaires reporting on 35597 colonies and, in contrast with a preliminary report (88 questionnaires; Giray et al., 2007), provides a broad representation of geographical regions, a better estimate of regional colony losses, and novel insights such as on colony collapse disorder (CCD) symptoms and losses.

Questionnaires were collected through an academic and trade journal for beekeeping (U. Bee J.), local beekeeping organizations, their field representatives, the internet, and Turkish mail. Returned questionnaires (see supplemental information S1) included names and contacts of beekeepers. The results were coded and analyzed by different authors

Corresponding author: T. Giray, tgiray2@yahoo.com

* Manuscript editor: David Tarpy

Online material is available at:

http://www.apidologie.org to maintain blindness and confidentiality. Statistical analyses were performed using $\mathrm{JMP}^{\mathrm{TM}}$ (v. 6).

We investigated the effects of: (1) location and migration of colonies; (2) beekeeper information (e.g., experience, interest, education); (3) honey, brood, and bee populations in colonies; (4) yearly losses from 2003 to 2007 in each operation; (5) queen source and replacement frequency; (6) colony feeding practices; (7) presence of major diseases and control methods; (8) reported bee race, wax foundation source, and outside environment (e.g. weather conditions); (9) presence of CCDlike symptoms (whether: i. colony populations decreased precipitously; ii. colonies remained with brood but only few workers and the queen; iii. honey was present; iv. wax moth or other kleptoparasites were absent; Oldroyd, 2007).

Responses were obtained from 61 provinces in 10 geographic regions, with $30 \pm 5$ beekeepers from each. Comparison to recent statistics demonstrate this sample to be representative of the general beekeeping population. Specifically, migratory beekeepers represented $85 \%$ of the responder population (compared to $75-85 \%$ reported in others), the average number of colonies per beekeeper was 123.6 (compared to 126 to 129 reported in others), the proportion of professional beekeepers was $33 \%$ (compared to $27 \%$ reported in others), and the type of beekeeping operation was $96 \%$ for honey production and $4 \%$ for queen production (see Günaydin 2008; Yilmaz; 2008).

Colony losses in 2006-2007 was the highest in comparison to previous years (Fig. 1A). The extraordinary losses $(>30 \%)$ were concentrated in 


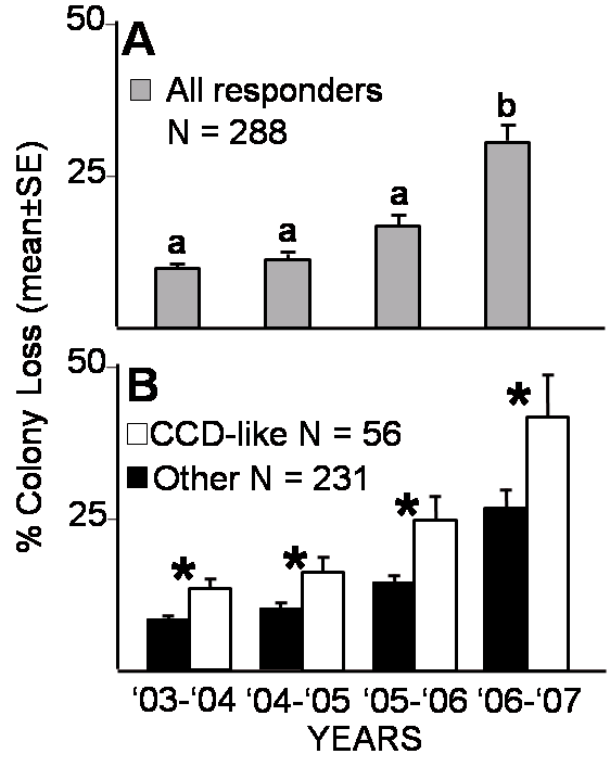

Figure 1. A. Percent colony losses (mean \pm SEM) in 2006-2007 and the three years prior. The bars with different letters indicate significantly different percent colony losses at $P<0.05$. B. Beekeepers reporting CCD-like symptoms in 2007 reported higher colony losses even in years where general losses were typical. * indicates a significant $(P<0.05)$ difference across colony mortality of beekeepers with (black bars) and without (white bars) CCD symptoms.

four geographic regions (see Fig. 2). There also were higher than $25 \%$ colony losses in Western Black Sea region. Bee losses reported for 2003 to 2006 were shown to be significantly correlated $(\mathrm{N}=288 ; 03-04$ vs. $04-05, \mathrm{r}=0.55 ; 03-04$ vs. $05-06, r=0.262 ; 04-05$ vs. $05-06 r=0.42$; all $P<0.0001)$ but not for 2006-2007 (06-07 vs. 03$04, \mathrm{r}=-0.085$; 06-07 vs. $04-05, \mathrm{r}=-0.059 ; 06-07$ vs. $05-06, \mathrm{r}=-0.037$; all $P>0.9$ ). In general, beekeepers reported in the fall of 2006 that only 26392 of the 35597 colonies survived to 2007 (pooled loss of $25.9 \%$, average loss per beekeeper $30 \%$ ). In previous years, losses were below $20 \%$.

In recursive partitioning analyses (De'ath and Fabricus, 2000), we identified beekeeping region, overwintering location, and unusual weather patterns to be important factors for mortality (see supplemental Fig. S2). In areas with high losses, beekeepers reported the weather to be warmer and drier than usual. However, extraordinarily wet weather conditions in the fall of 2006 were reported by beekeepers in the Northeastern regions, where the high- est losses were reported. The reported weather conditions agreed in general with data from National Meteorological Services of Turkish Republic (results not shown).

CCD-like symptoms were reported by 56 of the 288 responders (19.4\%). Distribution of symptoms in areas with high or low colony losses did not differ significantly ( 23 of 118 in regions with $\geqslant 30 \%$ loss, versus 33 of 169 in other regions; $X^{2}=0.0$, df $=$ $1, P=0.99)$. However, losses of beekeepers reporting CCD-like symptoms were significantly higher in 2007 than in the three previous years (Fig. 1B).

Factors not explaining colony losses included the type of beekeeping operation, characteristics of the beekeeper, foundation comb used, fall feeding of bees and feed type or source, source of queens, use of Varroa control chemicals in the colonies, urban vs. rural apiary locations, presence of industry near apiaries, and presence of known bee diseases as reported by the beekeeper. However, as a caveat, beekeepers appeared to observe diseases at a lower rate than expected (see Inci, 2008); Varroa destructor: $82 \%$, Nosema (not distinguished between N. apis or N. ceranae): $<9 \%$, and foulbrood (American, Paenibacillus larvae larvae; or European, Melissococcus plutonius), $<17 \%$.

In conclusion, in 2006-2007, extraordinary colony losses were reported in four regions in Turkey, which relate to weather conditions. High losses of colonies with CCD-like symptoms were independent of region. This is different than in the United States (see Handerson et al., 2007; vanEngelsdorp et al., 2008), and may indicate different causes of losses or different disease and host dynamics (see Maori et al., 2007).

For future monitoring, comparing individual operation losses to average losses in an area and comparing meteorological conditions to long-term data could provide early warnings. In the field, for research into causes of bee losses, long-term monitoring and locally occurring contaminants or diseases appear to be priorities (see Oldroyd, 2007). Because losses in regions varied over the years, beekeeping inputs were not implicated and beekeeping locations and overwintering areas greatly differed for colony losses.

\section{ACKNOWLEDGEMENTS}

We thank all beekeepers who contributed to this study, Uludag Beekeepers Association, Turkish Association of Beekeepers, "Turkish Foundation to Combat Soil Erosion" (TEMA) for help with collection of questionnaires. Drs. I. Cakmak, L. Aydin, 


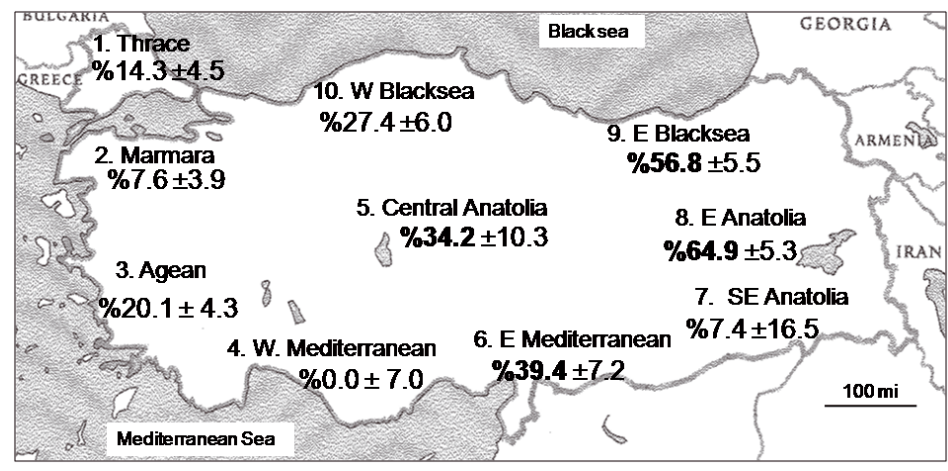

Figure 2. Percent colony losses (mean \pm SE) in 2006-2007 in ten different regions of Turkey. Similar number of questionnaires $(30 \pm 5)$ were collected and analyzed from regions independent of the level of colony losses.

I. Kandemir helped in early stages of this work. Comments by anonymous reviewers helped improve the manuscript.

Note scientifique : étude sur les pertes de colonies d'abeilles en Turquie et les causes de cette mortalité.

Eine wissenschaftliche Notiz: Erfassung von Völkerverlusten in der Türkei und Gründe für Bienenverluste.

\section{REFERENCES}

Bodur Ç., Kence M., Kence A. (2007) Genetic structure of honeybee, Apis mellifera L. (Hymenoptera: Apidae) populations of Turkey inferred from microsatellite analysis, J. Apicult. Res. 46, 60-67.

De'ath G., Fabricus K.E. (2000) Classification and regression trees. A powerful yet simple technique for ecological data analysis, Ecology 81, 3178-3192.

EFSA (European Food Safety Agency) (2008) A report by the Assessment Methodology Unit in response to Agence de Securite Sanitaire des Aliments (AFSSA): Bee mortality and bee surveillance in Europe, EFSA J. 154, 1-28.

FAOSTAT (2008) ProdSTAT Database. Food and Agriculture Organization of the United Nations, available at http://faostat.fao.org/site/573/DesktopDefault.aspx? PageID=573\#ancor, version updated June 11, 2008, last accessed in June 13, 2009.
Giray T., Cakmak I, Aydin L., Kandemir I., Inci A., Oskay D., Doke M.A., Kence M., Kence A. (2007) Preliminary survey results on 2006-2007 colony losses in Turkey, U. Bee J. 7, 101-107.

Günaydin G. (2008) Economic and political analysis of beekeeping in Turkey, (in Turkish), Proceedings of the 1st International Mugla Beekeeping and Pine Honey Congress, Mugla Univ. Press, Turkey, pp. 3-10.

Handerson C., Tarver L. Plummer D., Seccomb R., Debnam S., Rice S., Bromenshenk J. (2007) US national bee colony loss survey: preliminary findings with respect to Colony Collapse Disorder, Bee Alert Technology Inc., March 26, 2007.

Inci A. (2008) Risks for Turkish beekeeping (in Turkish), available at http://www.inciari.com/tema2.htm, TEMA Foundation Publications, Istanbul, Turkey.

Kence A. (2006) Genetic diversity of honey bees in Turkey and the importance of its conservation, U. Bee J. 6, 2532.

Maori E., Tanne E., Sela I. (2007) Reciprocal sequence exchange between non-retro viruses and hosts leading to the appearance of new host phenotypes, Virology 362, 342-349.

Oldroyd P.B. (2007) Unsolved mystery: what's killing American honey bees? PLoS Biol., doi:10.1371/journal.pbio.0050168.g001.

vanEngelsdorp D., Hayes J. Jr., Underwood R.M., Pettis J. (2008) A survey of honey bee colony losses in the U.S. Fall 2007 to Spring 2008, PLoS ONE 3(12):e4071, doi:10.1371/journal.pone.0004071.

Yilmaz B. (2008) Beekeeping Report of Turkey (in Turkish). Proceedings of the 1st International Mugla Beekeeping and Pine Honey Congress, Mugla Univ. Press, Turkey, pp. 191-197. 